\title{
PERANCANGAN APLIKASI EDUKASI PENGENALAN LAGU DAERAH DI INDONESIA BERBASIS ANDROID
}

\author{
Muhammad Ridwan ${ }^{1}$, Didik Wiguna ${ }^{2}$, Ana Rusmardiana ${ }^{3}$ \\ Program Studi Teknik Informatika, Fakultas Teknik dan Ilmu Komputer, \\ Universitas Indraprasta PGRI \\ Jalan Raya Tengah No 80, Kelurahan Gedong, Pasar Rebo, Jakarta Timur \\ ridwan0998@gmail.com¹, didik.wiguna@gmail.com², ana.irawan93@gmail.com³
}

\begin{abstract}
Abstrak
Di era yang serba modern ini semua orang bergantung dengan sebuah smartphone tidak terkecuali dunia pendidikan. Tujuan dari perancangan aplikasi pengenalan lagu daerah ini adalah membuat sebuah metode edukasi untuk mengenalkan berbagai lagu daerah setiap provinsi di indonesia mulai dari lirik lagu, deskripsi lagu serta audio lagu tersebut dengan berbasis android agar lebih mudah untuk di pelajari dan mengikuti perkembangan di era yang bergantung pada teknologi. Metode penelitian yang digunakan untuk aplikasi ini adalah metode deskriptif kualitatif yang menyajikan data berupa teks yang merinci dari penelitian tersebut. Sedangkan teknik yang digunakan penelitis adalah metode kepustakaan. Setelah Peneliti melakukan penelitian dapat mengambil kesimpulan aplikasi ini sudah sesuai yang diharapkan oleh peneliti dan user walaupun aplikasi ini belum sempurna karena masih terdapat kekurangannya.
\end{abstract}

Kata Kunci: Aplikasi, Edukasi, Android, Lagu Daerah.

\begin{abstract}
In this modern era everyone depends on a smartphone is no exception to the world of education. The purpose of designing this regional song recognition application is to create an educational method to introduce various regional songs of each province in Indonesia ranging from song lyrics, song descriptions and audio of the song with android-based to make it easier to learn and follow developments in an era that relies on technology. The research method used for this application is a qualitative descriptive method that presents data in the form of text detailing the research. While the technique used by the author is the method of literature. After the researcher conducted the study can conclude this application is in accordance with the expected by researchers and users even though this application is not perfect because there are still shortcomings.
\end{abstract}

Keywords: Application, Education, Android, Folk Songs.

\section{PENDAHULUAN}

Indonesia saat ini memiliki 34 provinsi. Setiap provinsi memiliki keanekaragaman budaya yang berbeda-beda, seperti : pakaian adat, rumah adat, senjata tradisional, alat musik adat, tarian adat, lagu daerah, suku, bahasa daerah, dan cerita rakyat yang dimiliki mulai dari Sabang sampai Merauke begitu banyak kebudayaan yang berbeda-beda dengan ciri khasnya ditiap daerah (Dharmawan \& Ismail, 2015). Namun saat ini sudah banyak kalangan yang menganggap tidak pentingnya mempelajari budaya lokal terutama lagu daerah. Padahal melalui pembelajaran tentang lagu daerah ini, kita dapat mengetahui ciri khas dari lagu daerah di berbagai provinsi yang ada di Indonesia serta melestarikannya. Akan tetapi saat ini belum tersedianya suatu Aplikasi mobile yang dapat meningkatkan minat belajar bagi orang tua, dewasa \& anak, dan juga belum tersedianya media atau Aplikasi mobile yang berbasis edukasi dalam ilmu pengetahuan tentang pengenalan lagu daerah di Indonesia yang berbasis Android. Lalu media saat ini yang menyajikan tentang lagulagu daerah juga masih kaku dan kurang diminati karena juga data-data informasi yang tidak akurat. Dengan dibantu Aplikasi mobile berbasis Android, ilmu pengetahuan dapat dikemas menjadi bentuk yang lebih menarik. Tujuan penelitian ini adalah membantu dan memudahkan pengguna dalam mempelajari dan meningkatkan akan ilmu pengetahuan tentang pengenalan lagulagu daerah di Indonesia serta bermanfaat untuk meningkatkan minat akan melestarikan lagu daerah pada orang tua, orang dewasa dan anak. 
Perancangan Sistem adalah sekumpulan aktivitas atau kegiatan yang menggambarkan secara rinci bagaimana sistem akan berjalan. Hal itu bertujuan untuk menghasilkan produk perangkat lunak yang sesuai dengan kebutuhan user (Shofroh, 2015). Aplikasi dapat diartikan sebagai suatu program berbentuk perangkat lunak yang berjalan pada suatu sistem tertentu yang berguna untuk membantu berbagai kegiatan yang dilakukan oleh manusia(Ibrahim, 2013). Pengertian edukasi adalah sebuah proses pembelajaran yang bertujuan untuk mengembangkan potensi diri pada peserta didik dan mewujudkan proses pembelajaran yang lebih baik(Edukasi, 2018). Lagu daerah adalah lagu atau musik yang berasal dari suatu daerah tertentu yang memiliki ciri khas dari daerah itu sendiri dan menjadi populer dinyanyikan baik oleh rakyat daerah tersebut maupun rakyat lainnya(Amalia, 2017). Android menyediakan platform terbuka bagi para pengembang untuk menciptakan aplikasi mereka sendiri untuk digunakan oleh bermacam peranti (yudik, 2017).

\section{PENELITIAN RELEVAN}

Penelitian pertama adalah penelitian yang dilakukan oleh Resti Amalia dengan judul Aplikasi Ensiklopedia Lagu dan Tarian Tradisional Indonesia, Tujuan penelitian Aplikasi ini untuk mempelajari lagu dan tari tradisional Indonesia menjadi lebih mudah dengan menggunakan smartphone android serta memudahkan masyarakat dalam mengenal lagu dan tari tradisional Indonesia dengan menggunakan smartphone android (Amalia, 2017).

Penelitian kedua adalah penelitian yang dilakukan oleh Wahyu Ardiansyah dan Dita Rizki Amalia dengan judul Pembangunan Aplikasi Media Pembelajaran Lagu Daerah Berbasis Teknologi Multimedia, Tujuan penelitian Aplikasi ini untuk mengetahui peningkatan pelestarian budaya melalui multimedia dengan melakukan sebuah riset (Ardiansyah \& Amalia, 2017).

\section{METODE PENELITIAN}

Metode penelitian adalah metode yang digunakan untuk mengetahui hasil dari penelitian dengan cara mengumpulkan, mencatat, dan menganalisis informasi data yang ada(Nasution, Ismawan, \& Heriyati, 2020). Metode penelitian yang digunakan oleh penelitis adalah grounded research yaitu metode penelitian berdasarkan dengan fakta dan menggunakan analisis perbandingan dengan tujuan mengadakan generalisasi empiris, menetapkan konsep, mengembangkan teori, membuktikan teori, pengumpulan dan analisis data dalam waktu yang bersamaan (Dewi, 2020). Dengan ini Model Waterfall menjadi pilihan yang digunakan dalam pengembangan. Metode waterfall adalah pengerjaan dari suatu sistem dilakukan secara berurutan atau secara linear (Bahiy, 2017). Model ini mengusulkan sebuah pendekatan perangkat lunak yang sistematik dan sekuensial yang dimulai pada tingkat dan kemajuan sistem pada seluruh analisis, desain, kode, pengujian dan pemeliharaan.

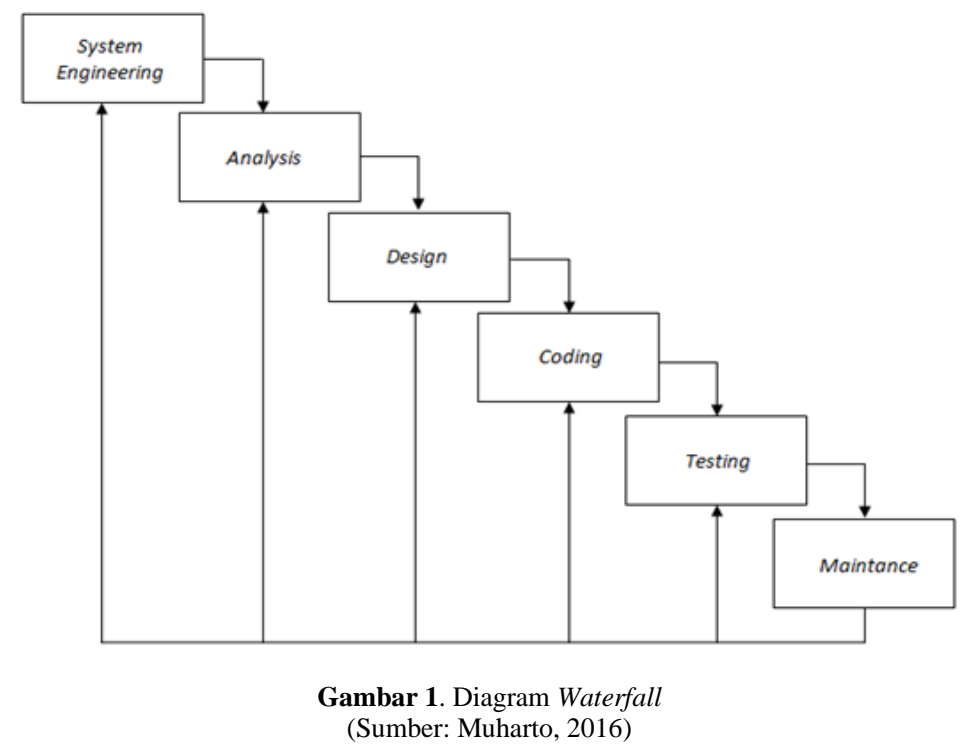




\section{HASIL DAN PEMBAHASAN}

Aplikasi pengenalan lagu daerah di Indonesia ini merupakan aplikasi edukasi yang ditujukan sebagai solusi persoalan sosial budaya di masyarakat Indonesia yang sudah semakin rendah kepeduliannya terhadap budaya dan tradisi indonesia khususnya lagu daerah masuknya budayabudaya modern seperti lagu-lagu modern semakin dilupakannya lagu daerah di Indonesia ini. Dengan perkembangan teknologi yang pesat sehingga penelitis termotivasi untuk membuat sebuah aplikasi berbasis android mengenai edukasi tentang lagu-lagu daerah di Indonesia dan didukung juga kondisi gaya hidup masyarakat Indonesia yang saat ini menjadikan smartphone sebagai kebutuhan dalam setiap aktivitasnya sehari-hari.

Berikut adalah perancangan flowchart dan Tampilan uji coba untuk Aplikasi Edukasi Pengenalan lagu daerah di Indonesia Berbasis Android.

\section{Flowchart Tampilan Splash Screen}

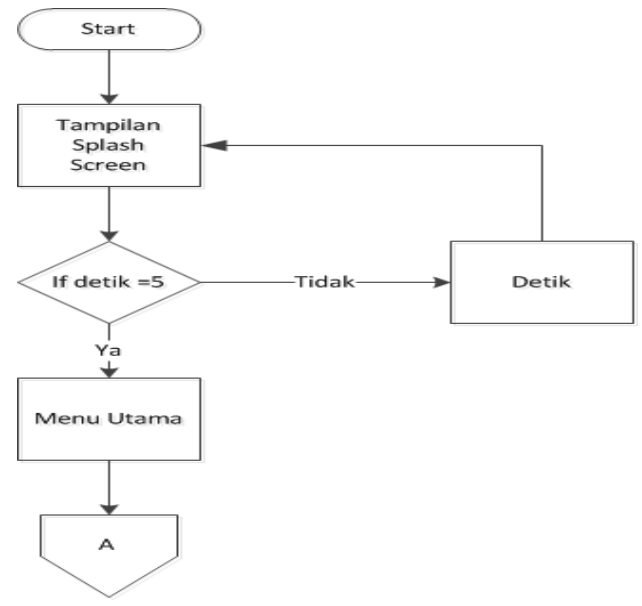

Gambar 2. Flowchart Splash Screen

\section{Flowchart Tampilan Menu Utama}

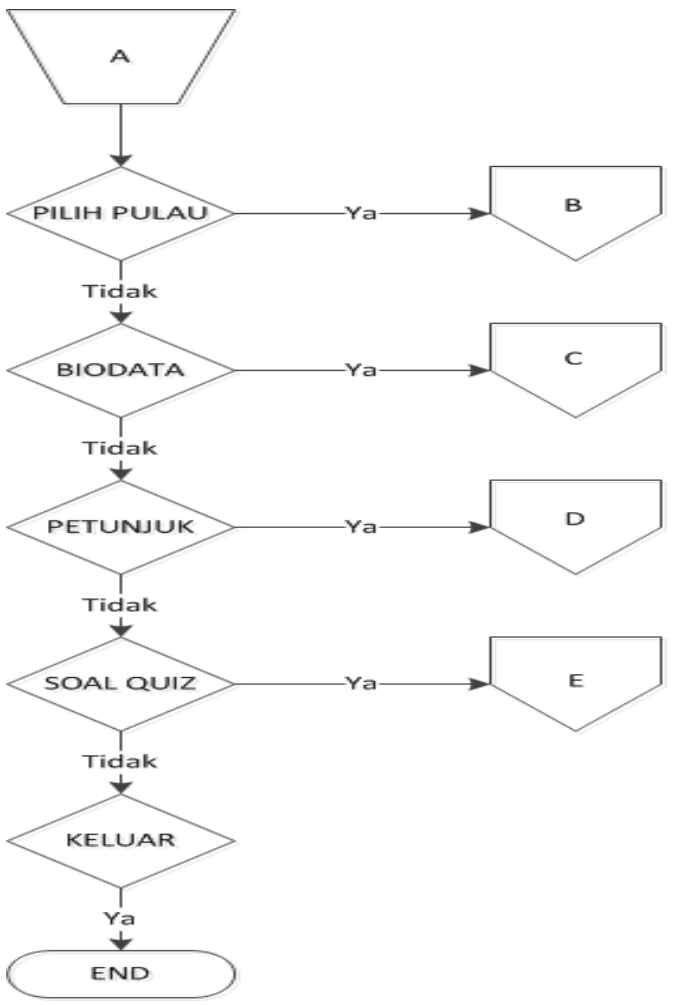

Gambar 3. Flowchart Tampilan Menu Utama 


\section{Flowchart Tampilan Menu Lagu Darah}

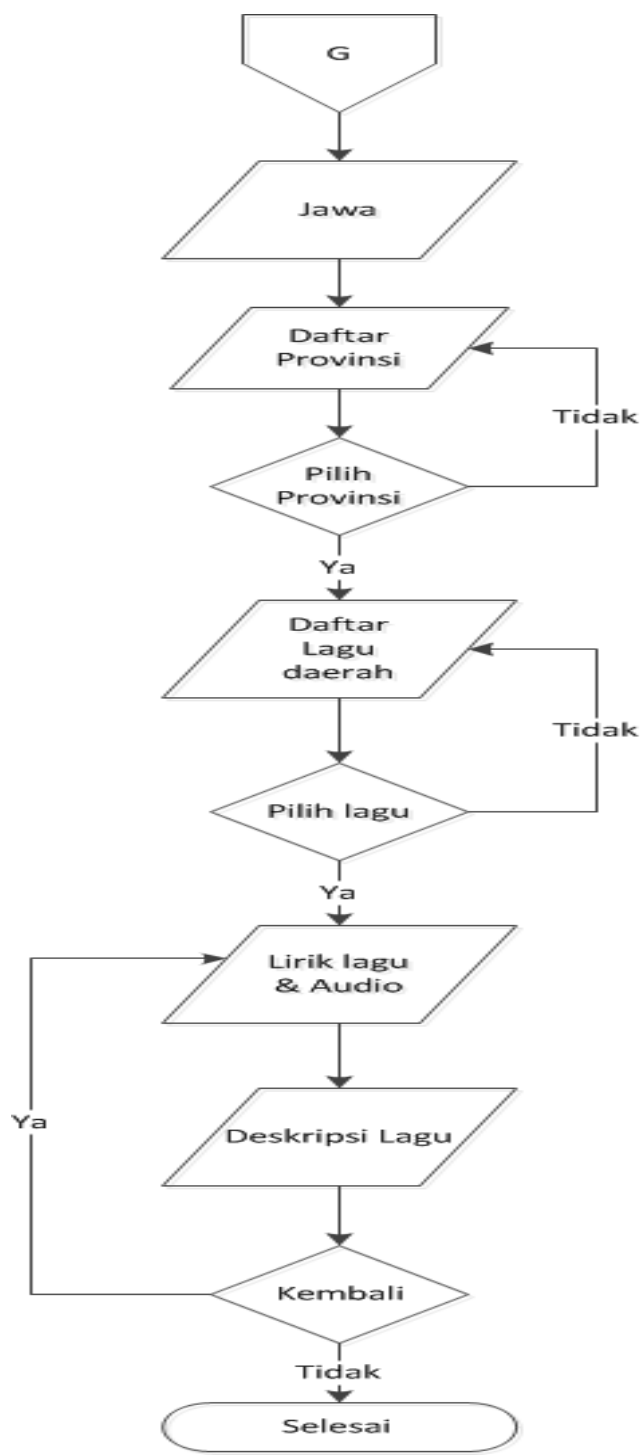

Gambar 4. Flowchart Tampilan Menu Lagu Daerah

\section{Flowchart Tampilan Menu Petunjuk}

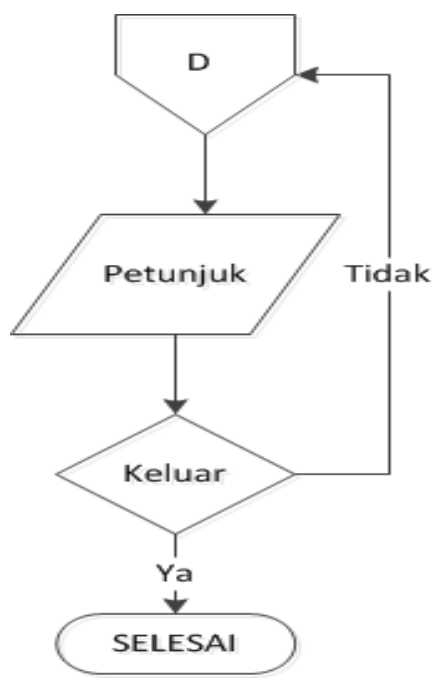

Gambar 5. Flowchart Tampilan Menu Petunjuk 


\section{Flowchart Tampilan Menu Biodata}

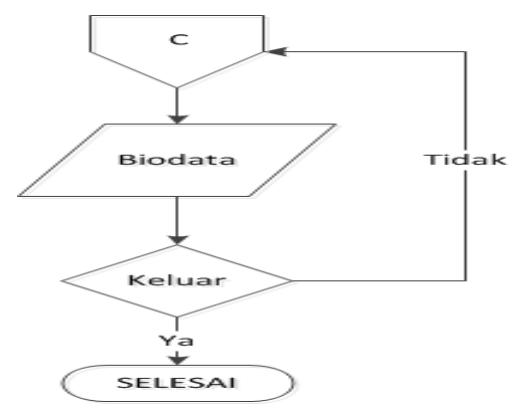

Gambar 6. Flowchart Tampilan Menu Biodata

\section{Flowchart Tampilan Menu Quiz}

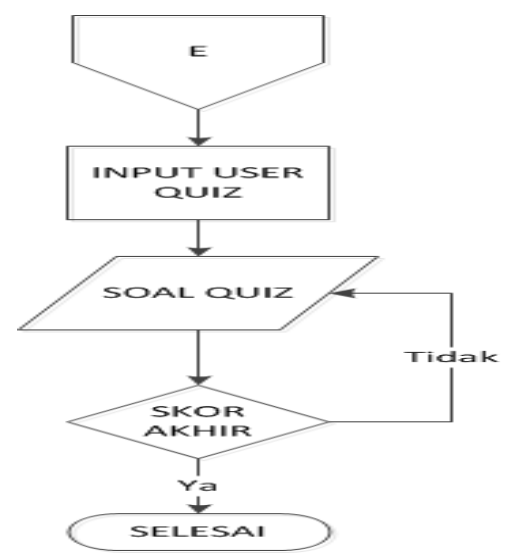

Gambar 7. Flowchart Tampilan Menu Quiz

\section{Hasil Uji Coba}

Untuk pembuatan Aplikasi edukasi pengenalan lagu daerah berbasis android ini penelitis menggunakan Android Virtual Device (AVD) yang ada Android studio dan smartphone berbasis Android. Berikut tampilan hasil uji coba program.

\section{Tampilan Uji Coba Splash Screen}

Pada awal membuka aplikasi akan muncul tampilan splash screen selama 3 detik sebelum masuk ke menu utama

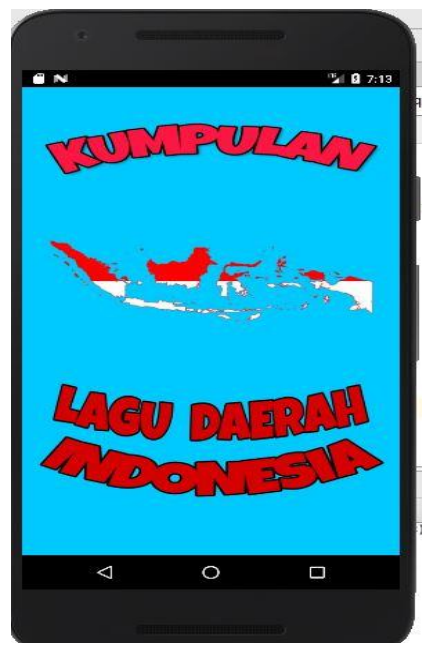

Gambar 8. Tampilan Uji Coba Splash Screen 


\section{Tampilan Uji Coba Menu Utama}

Setelah tampilan splash screen akan masuk ke dalam menu utama yang terdiri dari menu pilih pulau, menu biodata, menu petunjuk dan menu quiz

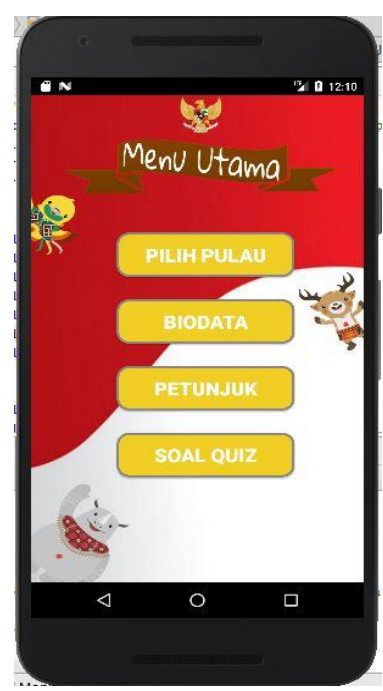

Gambar 9. Tampilan Uji Coba Menu Utama

\section{Tampilan Uji Coba Lagu Daerah}

Pada tampilan lagu daerah terdapat lirik lagu daerah tersebut serta button untuk memutar lagu daerah dan terdapat juga button deskripsi lagu untuk pindah ke halaman deskripsi lagu.

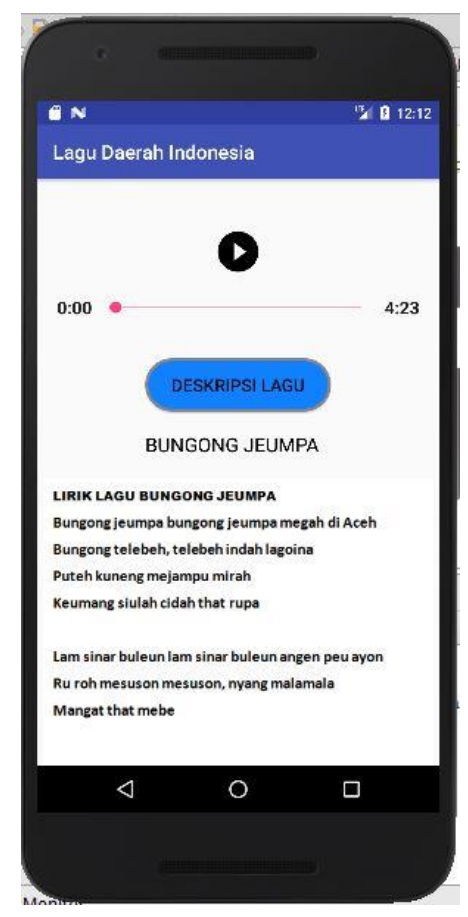

Gambar 10. Tampilan Uji Coba Lagu Daerah

\section{Tampilan Uji Coba Deskripsi Lagu}

Pada tampilan deskripsi lagu berisi mengenai judul 


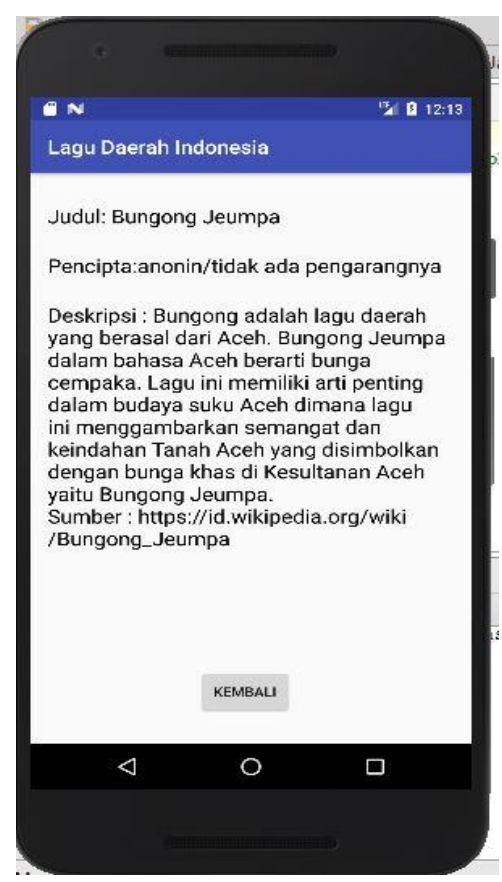

Gambar 11. Tampilan Uji Coba Deskripsi Lagu

\section{Tampilan Uji Coba Menu Quiz}

Untuk ke tampilan menu quiz, pada menu utama kita pilih button soal quiz setelah itu user harus mengisi nama setelah itu akan muncul soal quiz setelah selesai menyelesaikan soal quiz kita pilih button selesai maka akan muncul hasil skor dari jawaban yang telah di jawab.

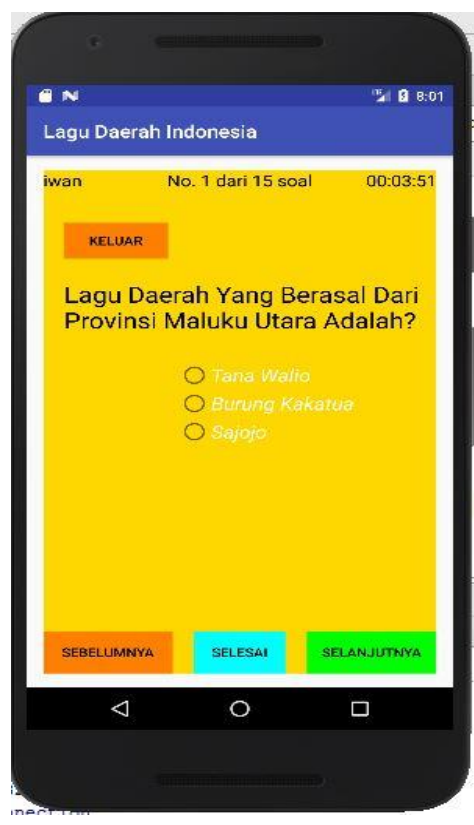

Gambar 12. Tampilan Uji Coba Quiz

\section{SIMPULAN}

Berdasarkan hasil dari penelitisan perancangan Aplikasi Edukasi Pengenalan Lagu Daerah Di Indonesia ini diharapkan dapat membantu masyarakat dalam memperoleh berbagai informasi mengenai lagu daerah di Indonesia sehingga dapat melesarikannya . Serta menumbuhkan kesadaran masyarakat akan budaya dan tradisi di tanah air yang semakin lama dilupakan. Aplikasi ini terdiri dari 7 pulau dan 34 provinsi yang ada di Indonesia, dan memiliki beberapa keunggulan diantaranya 
terdapat menu quiz sebagai pembelajaran dan tampilan yang menarik. Aplikasi ini dibuat untuk memudahkan pengguna dalam mengakses informasi melalui Android secara efektif dan mudah.

\section{DAFTAR PUSTAKA}

Amalia, R. (2017). Aplikasi Ensiklopedia Lagu dan Tarian Tradisional Indonesia Berbasis Android. Jurnal Informatika Universitas Pamulang, 2(1), 20. https://doi.org/10.32493/informatika.v2i1.1501

Ardiansyah, W., \& Amalia, D. R. (2017). Pembangunan Aplikasi Media Pembelajaran Lagu Daerah Berbasis Teknologi Multimedia. Jurnal ICT : Information Communication \& Technology, 16(2), 48-52. https://doi.org/10.36054/jictikmi.v16i2.22

Bahiy. (2017). Metode Waterfall (Kelebihan dan Kelemahan). Retrieved from http://bahiy.blogger.mercubuana.ac.id/2017/09/15/metode-waterfall-kelebihan-dan-kelemahan/

Dewi, S. S. (2020). Rekayasa Perangkat Lunak Resep Kuliner Nusantara Berbasis Android. Jurnal Riset Dan Aplikasi Mahasiswa Informatika (JRAMI), 1(3). https://doi.org/10.30998/jrami.v1i03.363

Dharmawan, A., \& Ismail, H. A. (2015). Aplikasi Pengenalan Budaya Indonesia Pada Sekolah Dasar Kristen 3 Yski Berbasis Android. Komputaki, 1(1), 157-169. Retrieved from http://www.unaki.ac.id/ejournal/index.php/komputaki/article/view/147/159

Edukasi. (2018). Pengertian edukasi menurut para ahli - edukasi. http://edukasi3.blogspot.com.

Ibrahim, A. (2013). Pengertian Aplikasi dan Sejarah Perkembangan Aplikasi _ Pengertian dan Definisi. Retrieved from http//: Pengertian Aplikasi dan Sejarah Perkembangan Aplikasi _ Pengertian dan Definisi.html

Nasution, P. S., Ismawan, F., \& Heriyati, H. (2020). Aplikasi Pengenalan Jenis Sayur-sayuran Berbasis Android. Jurnal Riset Dan Aplikasi Mahasiswa Informatika (JRAMI), 1(3). https://doi.org/10.30998/jrami.v1i03.384

Shofroh, S. R. (2015). Apa Pengertian Perancangan Sistem. Timur.ilearning.me/.

yudik. (2017). Pengertian Definisi Android - Android Enthusiast Blog. 